\title{
TEORI KRITIS: PERKEMBANGAN DAN RELEVANSINYA TERHADAP PROBLEMATIKA DI ERA DISRUPSI
}

\section{CRITICAL THEORY: DEVELOPMENT AND RELEVANCE TO PROBLEMATICS IN THE DISRUPTION ERA}

Irvan Tasnur ${ }^{1}$

Universitas Negeri Yogyakarta

\author{
Ajat Sudrajat ${ }^{2}$ \\ Universitas Negeri Yogyakarta
}

Irvantasnur@gmail.com

Ajat@uny.ac.id

\begin{abstract}
ABSTRAK: Perkembangan teknologi yang sangat masif di era disrupsi menimbulkan dampak positif dan juga membuka berbagai permasalahan-permasalahan baru dalam kehidupan bermasyarakat. Penelitian ini bertujuan guna meninjau latar belakang lahir dan berkembangnya teori kritis serta relevansinya apabila diterapkan pada masyarakat industri 4.0. Penelitian ini menggunakan metode hermeneutik dalam menjelaskan realitas yang terjadi. Hasil analisis didapatkan bahwa lahirnya teori kritis disebabkan oleh adanya dominasi ilmu pengetahuan, manusia, serta budaya yang diakibatkan oleh berkembangnya positivisme, liberalisme dan kapitalisme pada masyarakat sehingga melahirkan cara pandang yang dilandaskan pada pemikiran pragmatis dan kacamata sains bahkan untuk mengamati fenomena sosial yang tidak dapat dijelaskan dengan metode tersebut, hal ini sering disebut sebagai perspektif one dimensional man. Teori kritis sebagai counter discourse terhadap hal tersebut bertujuan untuk menciptakan masyarakat kritis dan emansipatoris yang tidak terpaku pada usaha pemenuhan kebutuhan jasmani atau materil akan tetetapi juga rohani. Teori ini berkembang dalam tiga fase utama di mana tisp fasenya tersebut terdapat sejumlah tokoh yang berusaha menjelaskan teori kritis dari berbagai paradigma yang berbeda serta berusaha saling mengkritisi guna mendapatkan formulasi yang tepat. Namun, walaupun terdapat perbedaan, inti dari pemikiran tersebut bermuara pada pembentukan masyarakat kritis guna menangkal perspektif one dimensional man yang tidak emansipatoris. Hasil analisis juga didapatkan bahwa teori kritis masih sangat relevan diterapkan pada masyarakat industri 4.0 dimana teknologi dan kapitalisasi mengarah kepada dehumanisasi, namun hal yang harus diperhatikan dalam penerapannya adalah penggunaan metode yang matang dalam proses aplikasinya, agar teori tersebut tidak mengarahkan pada suatu kerangka berpikir tertentu, sehingga membawa pada lahirnya dominasi baru.
\end{abstract}

Kata Kunci: Teori Kritis' ${ }^{1}$ Dominasi ${ }^{2}$, One dimentional man ${ }^{3}$

ABSTRACT: The development of technology that is very massive in the era of disruption has a positive impact and also opens up various new problems in social life. This study aims to review the background of the birth and development of critical theory and its relevance when applied to industrial society 4.0. This study uses the hermeneutic method in explaining the reality that occurs. The results of the analysis found that the birth of critical theory is caused by the dominance of science, humans, and culture that is caused by the development of positivism, liberalism and capitalism in society to give birth to a perspective based on pragmatic thinking and scientific glasses even to observe social phenomena that cannot be explained with this method, this is often referred to as a one-dimensional man perspective. Critical theory as a counter-discourse on this matter aims to create a critical and emancipatory society that is not fixated on efforts to meet physical or material needs but also spiritual. This theory develops in three main phases where the phases of it are several figures try to explain critical theories from different paradigms and try to criticize each other to get the right formulation. However, despite differences, the core of this thinking leads to the formation of a critical society to counteract the 
non-emancipatory one-dimensional man. The results of the analysis also found that critical theory is still very relevant to be applied to industrial society 4.0 where technology and capitalization lead to dehumanization, but the thing that must be considered in its application is the use of mature methods in the application process so that the theory does not lead to a certain frame of mind, thus leading to the birth of new domination.

Keyword: Critical Theory', Domination'2, One dimentional man ${ }^{3}$

\section{A. PENDAHULUAN}

Filsafat sebagai landasan dan pijakan berpikir dalam dunia akademis memiliki pengaruh yang sangat besar. Sama halnya dengan ilmu pengetahuan, filsafat sebagai induk dari ilmu pengetahuan juga terus mengalami transformasi-transformasi guna mengentaskan semua problematika yang dihadapi pada zaman di mana filsafat tersebut lahir dan berkembang. Melihat kembali keberadaan historisnya, filsafat terus mengalami dinamika dalam setiap periodisasi sejarah, guna menuntut adanya perubahan mendasar dari pemikiran terdahulu terlebih setelah diadakannya eksplorasi mendalam untuk menyelesaikan berbagai permasalahan yang ada.

Masyarakat modern yang lahir pada abad ke tujuh belas sebagai dampak dari meletusnya revolusi industri di Eropa, menciptakan berbagai pemikiran dan pandangan idealis yang memiliki praksis dan pengaruh besar terhadap kehidupan masyarakat pada zaman tersebut. Hal ini tidak begitu mengherankan, karena apabila mengamati pola perubahan yang terjadi, paham yang muncul pada suatu zaman biasanya merupakan respons terhadap suatu rentetan peristiwa-peristiwa yang berdampingan dan mengokohkan antara satu sama lain. Dominasi gereja yang terjadi berabad abad lamanya merupakan alasan mendasar lahirnya positivisme yang kemudian semakin diperkuat oleh adanya sekularisme. Pengokohan ideologi ini kemudian semakin lengkap ketika liberalisme yang melahirkan kapitalisme menggunakan positivisme sebagai alat untuk melegitimasi keberadaannya dalam semua unsur sendi kehidupan masyarakat modern. Tujuan mendasar dari filsafatpun sedikit demi sedikit mengalami pergeseran dari tujuan substansinya.

One dimensional man adalah masalah mendasar yang kemudian dikaji oleh Institut Ilmu Sosial di Frankurt Jerman sebagai dampak dari positivisme. Hasil analisis dari institusi ini kemudian melahirkan sebuah mazhab baru dalam kajian filsafat yang dikenal dengan nama mazhab Frankurt. Kajian analisis dari mazhab ini menyangkut tentang masyarakat modern yang terbelenggu dengan adanya hasil ciptaan yang dilahirkan oleh positivisme serta cara pandang kebenaran yang berlandaskan pada 
pembuktian secara empiris dan teruji secara saintifik. Permasalahan dari hal ini sebenarnya terletak dari tujuan awal filsafat yang dianggap tidak memayungi semua kebutuhan substansi manusia.

Masalah-masalah yang dialami pada paruh waktu abad ke enam belas bila dicermati juga masih dialami masyarakat postmodern terlebih dengan gencarnya kampanye tentang revolusi industri 4.0. Masyarakat postmodern menghadapi berbagai permasalahan khususnya terkait dengan pandangan-pandangan mendasar mengenai ilmu, kebenaran, budaya serta emansipatoris. Maka dari itu, untuk melihat secara mendalam dan komprehensif terhadap permasalahan tersebut maka, penelitian ini mengkaji mengenai proses lahir dan berkembangnya teori kritis serta relevansinya di era disrupsi,

\section{B. METODE PENELITIAN}

Metode yang digunakan dalam penelitian ini yaitu hermeneutika. Hermeneutika digunakan sebagai metode penelitian agar makna-makna yang tersembunyi dalam realitas dapat ditafsirkan atau diinterpretasi lebih mendalam lagi agar mendapatkan suatu kejelasan yang komprehensif terhadap objek kajian yang diteliti. Adapun fokus kajian dalam penulisan ini adalah latar belakang lahirnya teori kritis, perspektif teori kritis di berbagai dimensional, serta relevansi teori kritis terhadap masyarakat di era disrupsi. Sedangkan tujuan dari penelitian ini adalah mengetahui secara mendalam proses lahir dan berkembangnya teori kritis serta relevansinya terhadap masyarakat di era disrupsi.

\section{HASIL DAN PEMBAHASAN}

\section{Latar Belakang Lahirnya Teori Kritis}

Filsafat merupakan induk dari pengetahuan dan landasan berpikir keilmuan yang menentukan cara berpikir. Masyarakat sebagai mahluk sosial yang mempunyai kebutuhan substansial, dan untuk memenuhi kebutuhan tersebut memerlukan suatu konsep dan metode berpikir ilmiah guna mencapai tujuan yang diinginkan. Maka dari itu, filsafat sebagai induk dari beberapa jenis metode berpikir, terus mengalami perkembangan dan transformasi untuk menyesuaikan dengan kebutuhan zaman di mana filsafat itu dilahirkan.

Secara epistemologi filsafat merupakan padanan kata falsafah (bahasa Arab) dan philoshopy (bahasa Inggris) yang diadaptasi dari bahasa Yunani philosophia, 
Kata philosophia sendiri terdiri dari dua kata utama yaitu philo yang berarti sahabat atau kekasih dan shopi yang berarti kebijaksanaan, kearifan atau dapat pula berarti pengetahuan ${ }^{1}$. Filsafat sebagai ilmu memiliki sifat dinamis sehingga perkembangannya akan berlangsung secara terus menurus. Salah satu aliran filsafat yang lahir dalam sejarah adalah teori kritis. Teori kritis ini memiliki misi guna membuat filsafat dan ilmu pengetahuan sebagai praksis terhadap emansipatoris ${ }^{2}$.

Pada awalnya teori kritis merujuk pada beberapa pemikiran tokoh-tokoh filsafat yang tergabung dalam lembaga penelitian di Universitas Frankrut, kemudian dikenal dengan nama Die Frankfurter Schule atau Frankrut School. Teori kritis di Jerman lebih dikenal sebagai madzhab Frankrut. Bila ditinjau dari latar belakang pendiriannya institut tersebut didirikan dikarenakan kemenangan revolusi Bolshevick serta kegagalan-kegagalan Revolusi di Eropa Tengah khususnya di Jerman. Teori ini dalam perkembangannya lebih banyak dipengaruhi oleh tokoh-tokoh utama filosof pendahulunya yakni seperti George Hegel, Karl Marx, Sigmund Freaud dan Imanuel Kant ${ }^{3}$. Pengaruh tokoh-tokoh tersebut merupakan suatu hal yang wajar, karena institusi tersebut pada awalnya didirikan bertujuan untuk melakukan penelitian-penelitian mengenai masyarakat yang berdasarkan pada landasan Sosialisme dan Marxisme.

Tokoh-tokoh yang termasuk dalam mazhab Frankurt adalah Max Horkheimer (1985-1973) dia menjadi direktur institut Für Zosialforschung (Lembaga Penelitian Sosial). tokoh yang kedua adalah Theodor Wiesengrund Adorno (1903-1969), Tokoh ketiga, Herbert Marcuse (1989-1979), adalah figur yang paling terkenal terutama karena ide-idenya memberikan inspirasi dan arah kepada gerakan "kiri baru" pada tahun 1960-an ${ }^{4}$. Freud Rush, Dkk Dalam bukunya yang berjudul The Cambridge Companion to Critical Theory membagi perkembangan teori kritis menjadi tiga generasi utama yakni Max Horkheimer, Friederich Pollack, Harbert Marcuse dan Theodor Adorno sebagai fase pertama teori kritis, tokoh fase kedua dalam perkembangan dari teori kritis yakni Jurgen Habermas yang kemudian dalam perkembangannya menjadi toko sentral pemikiran sosial, politik dan filsafat

\footnotetext{
1 Jan Hendrik Rapar, Pengantar Filsafat, Yogyakarta: Kansius, 2015, hlm. 14.

2 Iwan, 2014, "Menelaah Teori Kritis Jurgen Habermas" dalam Jurnal Edueksos: Jurnal Pendidikan Sosial dan Ekonomi, Fakultas IImu Tarbiyah dan Keguruan, IAIN Syekh Nurjati Cirebon, Vol III No. 2, 2014, hIm. 146.

${ }^{3}$ A. Setyo Wibowo, Para Pembunuh Tuhan, Yogyakarta: Kansius, 2009, hlm. 55.

4 Suseno, Franz Magnis, Pijar-Pijar Filsafat: dari Gatholoco ke Filsafat Perempuan, dari Adam Müller ke Postmodernisme, Yogyakarta: Kansius, 2005, hlm. 148.
} 
di Eropa, Fase ketiga dalam perkembangan teori kritis ini diteruskan oleh Axel Honne 5 .

Adanya tiga generasi dalam perkembangan teori kritis ini menunjukkan bahwa teori berjalan bukan hanya dalam kerangka teori belaka, namun juga terjadi dalam praktiknya yakni dalam mengkritik teori kritis yang dikemukakan oleh generasi sebelumnya ${ }^{6}$. Hal ini juga mengisyaratkan bahwa teori kritis tidak dilahirkan berdasarkan sifat monopolistik. Sifat yang dinamis dari teori kritis merupakan wujud dasar perkembangan filsafat yang akan terus mengalami perubahan dan perkembangan sesuai dengan kebutuhan atau kondisi di mana filsafat itu dilahirkan. Tujuan utama dari teori kritis adalah untuk mengubah arah baru filsafat dan cara berpikir masyarakat modern. Menurut teori kritis, filsafat bukan hanya harus menafsirkan dunia, namun juga harus mempunyai praksis yang dapat berkontribusi dalam perubahan dunia kerah yang lebih baik.

\section{Max Horkheimer: Perspektif Sejarah dalam Memandang Ilmu Pengetahuan.}

Pemikiran dari Mazhab Frankurt pada awalnya didasari oleh ketidakberhasilan teori-teori yang dicetuskan pada masa Aufklarung untuk mengubah wajah masyarakat. Teori yang dianggap sebagai solusi baru untuk memotong akar masalah yang kompleks hanya berakhir pada perubahan definisi terhadap realitas. Kemandulan praksis dari teori tersebut menyebabkan gerak perubahan tidak terjadi, namun hanya menjadi sebuah penggantian dominasi penguasaan yang tadinya dominasi tersebut berpusat pada simbolisasi agama, kini berganti didominasi oleh teori yang tidak menimbulkan perubahan di masyarakat. Proses kritik yang di lakukan oleh mazhab frankurt ini kemudian menyoroti berbagai aspek kehidupan masyarakat modern.

Pemikiran mengenai teori kritis yang dicetuskan oleh Horkheimer yang merupakan seorang direktur institut sosial Frankurt ini, merupakan hasil pemikiran dan pengamatan yang sangat panjang di tengah distorsi sosial yang menimpah masyarakat Eropa dan Amerika. Horkheimer memandang bahwa kapitalisme dan sistem feodal menciptakan dominasi terhadap individu. Individualisme yang

\footnotetext{
${ }^{5}$ Fred Rush, The Cambridge Companion to Critical Theory: Cambridge companions to philosophy, religion, and culture, Inggris: Cambridge University Press, 2004, hlm. 1.

${ }^{6}$ Paulus Rudolf Yuniarto, "Masalah Globalisasi Indonesia: Antara Kepentingan, Kebijakan dan Tantangan", Jurnal Kajian Wilayah, Volume 5, No. 1, Ristekdikti: Garda Rujukan Digital, hlm. 73-78.
} 
menjamin adanya kebebasan, dan di sisi lain pelaksanaan pasar bebas mempersempit ruang gerak individu disebabkan oleh adanya dominasi pemilik modal ${ }^{7}$.

Selanjutnya Horkheimer memandang bahwa dunia modern telah dirusak secara radikal oleh ilmu pengetahuan yang tidak terkendali lagi. Dalam rangka menyelesaikan masalah tersebut, perlu adanya perubahan secara masif di bidang teori dan praksis agar membawa perubahan-perubahan ke arah yang lebih positif. Masyarakat yang kritis adalah suatu hal yang semestinya kembali dilahirkan sebagai suatu solusi yang mendasar untuk menciptakan keteraturan masyarakat serta memperdalam pemaknaan terhadap hidup sebagai kebutuhan substansi dari masyarakat. Namun, untuk melahirkan ilmu sebagai suatu hal yang bermanfaat dan bermakna maka diperlukannya suatu pendekatan baru sebagai solusi monopoli pengetahuan yang dilakukan oleh positivisme.

Horkheimer memandang ketidak acuan terhadap landasan historis sebagai pembuktian kebenaran merupakan perampokan terhadap hak intelektual untuk menentukan yang "benar" dan "salah". Melanjutkan pandangan tersebut dia berusaha menggambarkan bahwa setelah terjadinya revolusi industri, kebenaran hanya bersumber dari hal-hal yang bersifat kuantitatif yang dapat ditransformasikan dalam bidang industri dan pengembangan teknologi. Dalam perkembangan selanjutnya ilmu tersebut yang bersumber dari landasan tradisional positivisme ini kemudian dijadikan sebagai alat untuk mengukuhkan kedudukan kaum kapitalis.

Walaupun Horkheimer menjadikan Marxisme sebagai landasan cara berfikir kritis yang dimilikinya, sebagai aliran kiri baru dia memandang filsafat spekulatif yang ditentang oleh Marxisme, masih diperlukan dalam menjamin keluarnya individu dari keterbelungguan cara berpikir yang disebabkan oleh positivisme. Fakta yang harus dibuktikan secara ilmiah dan teruji menurut aliran tradisional positivisme, masih diyakini sebagai hal yang perlu, namun cara pandang historis juga harus dijadikan sebagai pertimbangan cara berfikir yang relevan. Sudut pandang historis yang menggambarkan proses terjadinya dan terciptanya hingga perkembangan sebuah paham dan dampaknya terhadap masyarakat harus menjadi suatu pertimbangan sendiri menurut Horkheimer. Metode ilmiah yang memandang

${ }^{7}$ Sindung Tcahyadi, “Teori Sosial Dalam Perspektif Teori Kritis Max Horkheimer”, Jurnal Filsafat, Volume 17, No 1 , Fakultas Filsafat, Universitas Gadjah Mada, 2007,hlm. 2. 
segala sesuatu dari perspektif fakta (being), harus kembali dipertimbangkan, karena menurut Horkheimer ilmu tidak harus dipandang melulu hanya untuk memenuhi kehidupan sehari-hari namun juga memenuhi kebutuhan yang bersifat substansial bagi manusia yakni kebutuhan rohani, maka dari itu ilmu juga harus dipandang dari sisi proses (becoming).

Terkait dengan perspektif kesejarahan sebagai instrumen yang digunakan dalam memandang sebuah ilmu, Horkheimer berpendapat bahwa hal tersebut sangat diperlukan. Walaupun sejarah digunakan sebagai kacamata dalam memandang ilmu pengetahuan, namun sejarah masih dikontrol dan dapat dikritik oleh filsafat sehingga pengetahuan yang dihasilkan dapat teruji seperti halnya positivisme. Landasan sejarah yang digunakan cara pandang Horkheimer ini banyak dipengaruhi oleh filsafat sejarah Hegel.

Bila melihat cara pandang Horkheimer di atas, dapat di abstraksikan bahwa terdapat tiga karakteristik utama teori kritis yang dikemukakan olehnya. Pertama, diarahkan sebagai suatu kepentingan fundamental untuk mengarah kepada perubahan masyarakat. Selanjutnya, teori kritis harus berlandaskan kepada cara berfikir yang bersifat historis. Terakhir, lahirnya teori kritis sebagai sebuah upaya pengembangan cara berfikir komprehensif ${ }^{8}$. Pemikiran - pemikiran tersebut berkembang di tengah masyarakat yang terjebak dalam one dimensional man sebagai akibat berkembangnya positivisme yang diarahkan kepada legitimasi personal para kapitalis.

\section{Herbert Marcuse: Emansipatoris Masyarakat Industri}

Marcuse lahir di Berlin pada tahun 1898, merupakan salah seorang guru filsafat politik di San Diego, Universitas California. Dia bergabung dengan institut ilmu sosial Frankurt di Jerman, namun menjelang Hitler berkuasa (1932) dia dan rekan-rekannya mengungsi ke Amerika Serikat ${ }^{9}$. Dia adalah orang yang paling lantang menyuarakan tentang terjadinya dominasi yang dilakukan oleh teknokrat. Dominasi ini bukan hanya terjadi dalam lingkup filsafat, dan ilmu pengetahuan namun mencakup semua rana dalam kehidupan bermasyarakat.

\footnotetext{
${ }^{8}$ Yesril Anwar, Pengantar Sosiologi Hukum, Jakarta: Gramedia Widiasarana, 2011, hlm, 59.

${ }^{9}$ Ginting Suka, "Dominasi dalam perspektif Teori Kritis", Jurnal Antropologi Volume XII, No. 1 Fakultas Sastra, Universitas Udayana, 2012, hlm. 45.
} 
Marcuse memiliki pandangan bahwa, masyarakat industri pada saat ini merupakan masyarakat yang tidak sehat, karena masyarakat hanya memandang segala sesuatu dari dimensi satu yang hanya mempunyai satu tujuan utama yakni menjamin keberlangsungan dan sistem yang talah ada dan sedang berjalan. Akibatnya, sistem kapitalisme yang sedang berjalan semakin kuat menancapkan akarnya karena didukung oleh perkembangan teknologi, informasi dan komunikasi. Dominasi yang terjadi diungkapkan oleh Marcuse dalam bukunya One Dimensional Men: Studies in the Ideology of Advanced Industrial Society bahwa: masyarakat industri yang membuat teknologi dan sains berhasil secara efektif mendominasi manusia dan alam, yang pada tujuan awalnya hanya untuk mendominasi alam ${ }^{10}$.

Pemikiran yang dikemukakan Marcuse kemudian mengarah kepada usaha untuk menjelaskan keterbelengguan manusia yang seharusnya bebas yang terjamin dalam suatu sistem liberalis. Agak berbeda dengan cara pandang Horkheimer, Marcuse melihat dominasi yang terjadi di zaman ini bukan lagi dilakukan oleh sesama manusia, namun hal-hal yang bersifat tidak diketahui atau anonim. Maksud dari anonim adalah dominasi yang terjadi secara tidak langsung dan tidak sadar, kebenaran yang bersumber dari positivisme yang kemudian melahirkan teknologi, mendominasi berbagai lini kehidupan manusia. Dominasi ini menyebabkan terjadinya one dimensional man ke arah pembenaran yang melegalkan suatu sistem. Marcuse kemudian menawarkan untuk tidak menyerahkan kemanusiaannya kepada teknologi agar manusia bebas untuk mencari eksistensinya sebagai individu yang bebas sehingga dapat melahirkan kreativitas dan inovasi-inovasi baru di segala lini kehidupan.

Terbelenggunya manusia oleh teknologi bukan hanya terjadi pada satu bidang tertentu, tetapi mengarah kepada dominasi secara universal semua lini kehidupan manusia. Bukan hanya terjadi pada negara maju tetapi juga pada negara berkembang, selain itu dominasi yang dilakukan oleh teknologi tidak memilih jenis ideologi tertentu, bahkan Marcuse menjelaskan bahwa teknologi menguasai sistem ekonomi dan politik negara liberalis maupun komunis ${ }^{11}$. Bila menelaah buah pikiran Marcuse, dominasi yang dilakukan teknologi adalah sebuah irasionalitas di

${ }^{10}$ Herbert Marcuse, One Dimensional Men: Studies in the Ideology of Advanced Industrial Society, London: Routledge \& Kegal Paul, 1964, hlm. 17.

11 Zaprulkhan, Filsafat IImu: Sebuah Analisis Kontemporer, Depok: Raja Grafindo, 2019, hlm. 287. 
tengah-tengah masyarakat rasional. Terjadinya hal demikian, disebabkan dominasi teknologi tidak akan terlacak karena sifatnya yang anonim dan telah mengakar menjadi suatu kebutuhan dalam menghasilkan produktivitas dan melegalkan dominasi kaum tertentu.

Terpenuhinya kebutuhan isi perut, memudahkan pekerjaan, bertambahnya waktu libur, memanjakan mata, banyaknya hiburan sebagai dampak perkembangan teknologi menyebabkan manusia menghilangkan unsur kritis yang ada dalam dirinya. Mereka tidak menyadari bahwa apapun yang mereka lakukan masih dalam kontrol dari teknologi. Adanya waktu luang yang kemudian dimanfaatkan dengan berlibur ke destinasi wisata tertentu merupakan suatu kontrol yang tidak terlihat dari adanya pengiklanan oleh media-media. Hal inilah yang menurut Marcuse menjadi penyebab hilangnya kemampuan kritis dan cara berpikir negatif tentang masyarakat sehingga totalitarian teknologi kokoh di puncak kejayaannya.

\section{Friederich Pollack: A New Order}

Pollack adalah seorang ekonom, sosiolog, dan filosof yang bergabung menjadi anggota Institut Sosial Frankurt, Jerman. Sama halnya dengan anggota lain yang tergabung dalam institut tersebut, Pollack juga menyoroti masyarakat yang terbelenggu dengan paradigma positivisme. Menurut pandangannya kapitalisme yang pada abad ke sembilan belas lahir sebagai upaya pembentukan a new order menggantikan feodalisme telah gagal mengantarkan perubahan ke arah kemajuan dalam bidang sosial dan ekonomi.

Pollack dalam artikelnya yang berjudul is Nationalism Socialism a New Order yang termuat dalam jurnal Studies in Philosophy and Social Since meragukan sistem kapitalisme yang dianggap sistem tatanan sosial baru yang berhasil menggantikan sistem feodal yang telah lama mengakar dalam sendi kehidupan masyarakat ${ }^{12}$. Menurutnya kapitalisme yang dipandang sebagai new order gagal membawa suatu perubahan signifikan disebabkan karena terjadinya dominasi antara masyarakat yang seharusnya mempunyai kedudukan sama sehingga tatanan yang diimpikan yaitu tidak adanya dominasi bisa cepat terwujud.

Kesangsian terhadap sistem kapitalisme yang seharusnya menjadi jalan keluar terhadap permasalahan yang ditimbulkan oleh sistem tradisional feodalisme.

${ }^{12}$ Friederich Pollack, Studies in Philosophy and Social Since, New York: The Institute of Social Reserch, $1941, \mathrm{hlm} .440$. 
Akibatnya, Pollack kemudian menawarkan konsep baru sebagai solusi permasalahan yang ditimbulkan oleh sistem kapitalisme. Konsep ini kemudian disebut sebagai Nationalism Socialism yang menawarkan perspektif baru pembentukan a New Order menggunakan landasan sosialis yang ditawarkan oleh pandangan The New Left.

\section{Theodor Adorno: Industrialisasi Budaya}

Adorno adalah seorang filosof, komposer, penulis essay, teoretis sosial yang lahir pada tahun 1903 di Frankurt, Jerman. Sebagai anggota institut ilmu sosial Frankurt, Adorno memiliki perspektif yang sama dalam mengkritisi masyarakat industri pasca perang dunia. Namun, walaupun konsep dasar para pendiri teori kritis berlandaskan pemikiran Hegel, dia tidak sepakat dengan teori totalitarianisme yang dikemukakan oleh Hegel. Baginya masyarakat tidak boleh didominasi oleh suatu paham apapun guna mewujudkan masyarakat yang kritis.

Ciri yang menonjol dalam pandangan teori kritis Adorno adalah penolakannya terhadap cara berpikir sistematis ${ }^{13}$. Dia berpendapat, usaha manusia untuk meninggalkan the dark age menuju pencerahan tidak berhasil. Mitos yang menjadi ciri khas zaman kegelapan telah dapat di reduksi sedemikian rupa, namun positivisme yang menjadi alat pencerah tidak mampu meyakini kebenaran dirinya sendiri tanpa melakukan eksperimen-eksperimen pembuktian.

Positivisme yang kemudian dijadikan sebagai alat untuk menghasilkan industrialisasi budaya yang di bawah ke arah komersialisasi menunjukkan pemahaman ini mengarah kepada sifat anti pencerahan. Industrialisasi budaya mengarah kepada manusia yang dipandang sebagai objek di mana manusia hanya dijadikan sebagai pekerja dan konsumen. Kondisi tersebut menyebabkan masyarakat tidak mampu berpikir secara dialektis dan logis.

Bagi Adorno budaya industri yang berkembang hanya berisi kebohongan yang menutupi kebudayaan original yang terbentuk secara alami. Komersialisasi budaya yang terjadi menyebabkan bergesernya paradigma budaya sebagai high culture menjadi low culture. Dia melihat bahwa manusia pada masa ini hanya memandang teknologi sebagai salah satu hasil budaya manusia akan berguna bila dapat menghasilkan bahan kebutuhan atau memenuhi kebutuhan hidup yang

\footnotetext{
${ }^{13}$ K. Bertens, Filsafat Barat Kontemporer: Inggris-Jerman, Jakarta: Gramedia Pustaka Utama, 2002, hlm. 209.
} 
bersifat jasmani. Bagi Adorno apabila pelegalan dan legitimasi budaya ini terus berlanjut akan menyebabkan kesemerautan dan adanya rasa tertekan, karena kebutuhan manusia bukan hanya bertumpu pada jasmani tetapi juga rohani.

\section{Jürgen Habermas: Kritisasi Terhadap Teori Kritis.}

Habermas merupakan seorang filosof asal Jerman yang dilahirkan pada tahun 1929. Sama halnya dengan pendahulu-pendahulunya, Habermas merupakan salah satu anggota di Institut Ilmu Sosial Frankurt Jerman walaupun dalam perjalanan karirnya, Dia memutuskan untuk pindah pada tahun 1970 di Max Planck Institute zur Erfoschung der Lebensbedingungen Wissenshaftlichtechnischen Welt (Institut Max Planck Untuk Penelitian Kondisi-Kondisi Hidup dari Dunia Teknis-Ilmiah) di Starnberg ${ }^{14}$. Kepindahannya tersebut menyebabkan Habermas dengan leluasa dapat mengembangkan pemikirannya mengenai teori kritis, dan membawa perubahan arah perkembangan pemikiran teori kritis.

Pemikiran Habermas bertitik tolak pada pendahulunya yaitu Adorno dan Horkheimer, dia merumuskan teori kritis sebagai sebuah "filsafat empiris sejarah dengan maksud praksis"15. Namun, Hasil-hasil karya Habermas lebih banyak diterbitkan setelah dia keluar dari Institut sosial Frankurt. Habermas banyak menyoroti teori kritis yang dikemukakan oleh pendahulunya. Baginya mazhab frankurt yang menyoroti permasalahan-permasalahan masyarakat modern yang berupa objektivitas sains, kegagalan praksis, tidak emansipatif, value free, melanggengkan status quo dan melupakan historisme dalam memandang ilmu pengetahuan, belum mampu menyelesaikan permasalahan yang ada. Diakibatkan teori Marxis, mazhab Frankurt, dan teori sosial positivistis dibangun atas dasar "paradigma kerja" sehingga memposisikan masyarakat sebagai objek secara $\operatorname{alamiah}^{16}$.

Habermas kemudian dalam teorinya berusaha mengembangkan konsep nalar yang lebih komprehensif, yakni nalar yang tidak tereduksi pada instrumen teknis dari subjek individu, dalam pengertian monad, yang kemudian memungkinkan

\footnotetext{
${ }^{14}$ Iwan, "Menelaah Teori Kritis Jurgen Habermas", Jurnal Edueksos: Jurnal Pendidikan Sosial dan Ekonomi, Vol III No. 2, Fakultas IImu Tarbiyah dan Keguruan, IAIN Syekh Nurjati Cirebon, 2014, 148.

15 Ajat Sudrajat, (tanpa tahun), Jurgen Habermas: Teori Kritis Dengan Paradigma Komunikasi, taken form http://staff.uny.ac.id/dosen/prof-dr-ajat-sudrajat-mag., on November , 12 ${ }^{\text {nd }}, 2018$, at $5.10 \mathrm{pm}$.

${ }^{16}$ F. Budi Hardiman, Pustaka Filsafat: Melampaui Positivisme dan Modernitas, Yogyakarta: Kansius, $2003, \mathrm{hlm} .61$.
} 
terbentuknya masyarakat yang emansipatif dan rasional ${ }^{17}$. Hal ini kemudian menghasilkan pengetahuan mengenai adanya hubungan keterkaitan antara ilmu dan kepentingan manusia yang dirumuskan oleh Habermas ke dalam tiga macam kepentingan yakni teknis (technical), Praktis (practical) dan emansipatoris (emancipatory).

Manusia modern menggunakan positivisme sebagai alat dalam rangga menguasai alam akan berubah kepada usaha untuk mendominasi sesama manusia. Bagi Habermas rasionalitas yang dijunjung tinggi dalam cara pandang positivisme, adalah sebuah hal yang baik bila bisa dikomuniskasikan secara inheren ke dalam kepentingan yang bersifat praktis dan emansipatoris. Namun, rasionalitas untuk kehidupan bersama hanya bisa diraih dengan suatu konsensus bersama yang diadakan tanpa adanya dominasi dari pihak atau individu tertentu.

Pandangan ilmu pengetahuan Habermas mengalami puncaknya pada pertengahan abad ke 20, di mana dia menghasilkan karya yang berjudul on the logic of social sciences and knowledge and human interests. Dalam pandangannya, Habermas menyoroti penerapan positivisme dalam ilmu-ilmu sosial, dengan mengatakan bahwa paradigma positivistik hanya sesuai bagi ilmu-ilmu alam yang tujuan akhirnya adalah mengontrol alam ${ }^{18}$. sedangkan, ilmu-ilmu sosial harus menggunakan pendekatan yang bersifat interpretatif.

Habermas berpendapat bahwa bentuk praksis ilmu pengetahuan bukan hanya dipahami sebagai bentuk kinerja akan tetapi juga harus dilihat sebagai sebuah bentuk komunikasi dan atau interaksi ${ }^{19}$. pemikiran tersebut kemudian berkembang menjadi sebuah pemahaman bahwa tujuan universal dari masyarakat adalah komunikasi. Proses komunikasi yang berlangsung antara manusia yang baik adalah memandang manusia bukan sebagai objek tetapi memandangnya sebagai subjek yang berkomunikasi intersubjek.

Masalah kemudian muncul apabila masyarakat yang komunikatif tersebut telah terbentuk kemudian mengalami suatu kendala dalam perjalanannya. Namun, masalah ini telah diantisipasi oleh Habermas dengan menawarkan proses penyelesasian yang bersifat argumentatif emansipatoris melalui perbincangan

\footnotetext{
${ }^{17}$ Kamaruddin, Paradigma Kritis Ilmu Sosial dan Komunikasi, Aceh: Universitas Malikussaleh, 2013, hlm. 6.

18 Ibid.

${ }^{19}$ Zuhri, ,"Hermeneutika dalam Pemikiran Jurgen Habermas", Jurnal Filsafat dan Pemikiran Islam; Refleksi, Volume 4, No. 12004 , Fakultas Usuluddin dan Pemikiran Islam, Universitas Islam Negeri Sunan Kalijaga, 2004, 17.
} 
(discourse) dan kritik bukan konfrontatif-represif. Namun, untuk menghindari unsur kepentingan masing-masing individu dalam proses argumentatif tersebut maka Habermas menawarkan kritik terapeutis yang menggunakan pendekatan hermeneutika.

\section{Abstraksi Teori Kritis: Meninjau Teori Kritis Menggunakan Paradigma Kritis.}

Mencoba menjelaskan inti dari pandangan ahli di atas, baiknya menggunakan cara berfikir kritis yang bersifat komprehensif. Menurut Ahmad Suhelmi dalam bukunya Pemikiran Politik Barat menjelaskan bahwa teori kritis adalah sebuah konsep akademis yang rumit dan sulit untuk dipahami, maka dari itu sulit untuk membuat suatu definisi yang jelas mengenai konsep teori kritis ${ }^{20}$. Selain itu, Isi dari paham teori kritis sulit untuk ditentukan karena mempunyai batasan ruang lingkup yang kurang jelas ${ }^{21}$. Maka dari itu, usaha untuk membuat suatu rumusan mengenai inti dari teori kritis diperlukan suatu usaha kajian yang mendalam terhadap pemikiran tokoh-tokoh tersebut.

Bila memperhatikan beberapa paradigma ahli yang menjadi landasan teori kritis di atas, dapat dilihat ada dua esensi utama yang dijadikan sebuah masalah, yakni yang berkaitan dengan identitas dan masalah yang terdapat dalam institusi kultural. Masalah identitas yang dimaksud adalah individu atau pribadi yang menggunakan cara pandang one dimensional man, serta memandang manusia hanya sebatas objek. Sedangkan, masalah institusi kultural adalah masalah yang terjadi dalam bidang agama dan pengembangan ilmu pengetahuan, di mana teori ini memandang bahwa ilmu yang berkembang pada masa ini menyebabkan terjadinya dikotomi antara orang yang diutamakan (kapitalis) dan merek yang dikesampingkan.

Menurut Samekto dalam bukunya Studi Hukum Kritis: Kritik Terhadap Hukum Modern menjelaskan bahwa terdapat tiga sifat utama dari teori kritis yakni selalu berusaha melakukan suatu perubahan yang mendasar dalam masyarakat dengan melakukan konstruksi terhadap tafsiran realitas, berusaha melakukan pendekatan historis terhadap segala peristiwa dan bersifat komprehensif terhadap

${ }^{20}$ Ahmad Suhelmi, Pemikiran Politik Barat, Jakarta: Gramedia Pustaka Utama 2001, hlm. 351.

${ }^{21}$ Munir Fuady, Filsafat dan Teori Hukum Postmodern, Bandung: Citra Aditya Bakti, 2006, hlm. 147. 
segala keadaan yang terjadi dalam masyarakat Bila diperhatikan sifat dari teori kritis tersebut, dapat diabstrakkan bahwa terdapat tiga hal mendasar dan utama dalam proses pembentuk dari teori kritis ${ }^{22}$. Pertama, selalu berpikir kritis dan curiga terhadap realita. Selanjutnya, memperhatikan aspek historis dan masyarakat dan terakhir tidak mendikotomi antara teori dan praktik, dan antara fakta dan nilai. Selain itu, bila ditelaah lebih jauh lagi teori ini sangat kritis terhadap pemanfaatan ilmu pengetahuan untuk memperkuat kedudukan penguasa sehingga tercipta masyarakat yang tidak emansipatoris.

\section{Relevansi Teori Kritis Pada Era Disrupsi}

Masyarakat postmodern atau masyarakat yang hidup di abad ke 21 merupakan kelompok masyarakat heterogen yang menyimpan segudang problematika yang tentunya jauh lebih kompleks dibandingkan dengan masyarakat modern yang hidup beberapa abad sebelumnya. Teknologi sebagai buah pikiran dari positivisme yang bertransformasi menjadi masalah besar pada syarakat modern juga masih terus berlanjut dalam konteks kekinian, bahkan perkembangannya jauh lebih masif dan lebih kompleks, sehingga upaya penyelesaian dari berbagai masalah yang ada harus dikaji secara komprehensif dan holistik. Bukti nyata perkembangan teknologi yaitu dengan adanya istilah disruption (disrupsi), yakni perubahan besar-besaran di segala sendi kehidupan masyarakat dan dalam segala bidang kehidupan manusia. Masyarakat superior yang mampu menyesuaikan diri melalui proses adaptasi terhadap sinkronisasi teknologi dalam segala sendi, secara tidak langsung akan memimpin jalannya kehidupan, dan nantinya akan bermuara pada proses mengontrol atau menghegemoni manusia lainnya. Bila dipertimbangkan lebih jauh lagi era tersebut akan membuat terjadinya dominasi dan distorsi sosial yang disebabkan oleh orang yang menguasai teknologi khususnya dunia maya atau internet.

Selain masalah yang ditimbulkan oleh disrupsi, globalisasi juga membawa dampak negatif terhadap kehidupan, sebut saja permasalahan seperti kemiskinan, pengangguran, ketimpangan pendapatan, ketergantungan terhadap input luar dan tertutupnya akses rakyat kecil, sebagai akibat kebijakan pasar bebas yang merupakan konsekuensi penerapan ekonomi liberal akhirnya melahirkan raja-raja

${ }^{22}$ Fx Adji Samekto, Studi Hukum Kritis: Kritik Terhadap Hujum Modern, Yogyakarta: Pustaka Pelajar, 2005, hlm. 39. 
kecil (kaum kapitalis) ${ }^{23}$. Permasalahan yang ditimbulkan oleh globalisasi kemudian semakin kompleks dengan adanya ketidakstabilan ekonomi, sehingga masyarakat berbondong-bondong untuk memenuhi kebutuhan jasmani dan mulai melupakan kebutuhan rohani yang juga merupakan kebutuhan substansial bagi manusia. Bila dilihat, permasalahan-permasalahan yang ada menyimpan kompleksitas besar dibandingkan dengan permasalahan pada era modern. Pada masyarakat modern, masalah itu diselesaikan dengan adanya teori kritis yang mencoba membentuk masyarakat kritis guna menghilangkan perspektif one dimensional man serta mencoba menciptakan masyarakat emansipatoris.

Teori kritis di era disrupsi bila dilihat dari sudut pandang kacamata ilmu pengetahuan sudah cukup berhasil diterapkan dalam kehidupan khususnya dalam perkembangan ilmu pengetahuan. Keberhasilan tersebut, dapat dilihat dengan berubah-nya arah pemikiran ilmu sosial dan banyaknya gugatan-gugatan terhadap ilmu sosial yang kajiannya masih berlandaskan pada filsafat positivisme. Ilmu sosial yang mengalami banyak proses kritik yakni ilmu sejarah, sehingga sejarah yang dahulunya berlandaskan positivisme mengalami suatu era baru dengan adanya deconstruction history, bahkan tercatat institusionalisasi otonom ilmu sosial pertama yang berdiri adalah ilmu sejarah ${ }^{24}$. Selain dalam perkembangan jenis kajian dan pendekatan ilmu pengetahuan, pengaruh teori kritis juga merubah pendekatan metodologi sebagai suatu langkah dalam melahirkan temuan baru dalam ilmu pengetahuan. Pendekatan kuantitatif sebagai metode mutlak dalam segala bidang ilmu pengetahuan, mulai ditinggalkan oleh ilmu sosial dan beralih kepada penggunaan metode kualitatif, namun perkembangan dari teori kritis serta berubahnya kebutuhan setiap zaman, membuat kebebasan berpikir sebagai prakarsa dari teori kritis dalam perkembangannya melahirkan mix method yakni penggabungan antara metode kuantitatif dan kualitatif.

Era disrupsi menyimpan permasalahan yang lebih kompleks dibandingkan dengan permasalahan mendasar era modern pada masa lampau. Masyarakat di era ini mulai cenderung lebih individualis disebabkan karena adanya tuntutan pemenuhan kebutuhan lahiriah seseorang. Komunikasi yang terjadi bukan

${ }^{23}$ Paulus Rudolf Yuniarto, Loc. Cit.

${ }^{24}$ Wallerstein, Immanuel, "Eourocentrism and Its Avatar: The Dilemas of Social Science" Sociological Buletin, (46) 1, March, SAGE Journals, 1997, hlm. 2. 
disebabkan untuk membangun keakraban dan persaudaraan, namun lebih mengarah unsur kepentingan, akibatnya kebutuhan atau kepuasan rohani tidak terpenuhi. Teori kritis apabila diterapkan dalam kehidupan masyarakat di era disrupsi tentunya memiliki dampak signifikan, pembangunan cara berpikir kritis sangat diperlukan di tengah perubahan teknologi, sistem distribusi, dan pasar yang mengarah kepada intensifikasi namun menimbulkan persaingan yang dapat mengarah kepada dominasi perlu dikaji secara lebih komprehensif.

Refleksi terhadap perkembangan era disrupsi harus dilakukan oleh masyarakat guna mengetahui esensi kebutuhan manusia. Refleksi diperlukan untuk menjawab pertanyaan-pertanyaan mendasar dalam masyarakat postmodern yang berkaitan dengan Apakah kita membutuhkan teknologi ?, sejauh mana teknologi itu membantu kita ?, seberapa perlu teknologi untuk keperluan sehari hari ?, seberapa mampu kita mengendalikan teknologi?, apakah teknologi mampu memenuhi kebutuhan substansi dari manusia baik jasmani maupun rohani?, apakah efisiensi adalah tujuan utama dalam bermasyarakat? apakah kita harus melawan arus perkembangan teknologi?. Pertanyaan-pertanyaan tersebut sebenarnya bila ditelaah secara mendalam, hanya dapat timbul pada mereka yang menerapkan cara berpikir kritis baik secara sadar maupun tidak sadar dalam dirinya. Pertanyaan yang timbul kemudian akan menciptakan keberagaman asumsi disebabkan karena pertanyaan tersebut hanya dapat dijawab oleh mereka yang mendesain kerangka pertanyaan tersebut.

Sesuai dengan tujuan dari teori kritis, pada masa revolusi 4.0 yang dikenal dengan era disrupsi, ilmu pengetahuan baik eksakta maupun sosial sudah mengalami transformasi dan perkembangan pesat akibat adanya kritik terhadap ilmu tersebut. Namun, di sisi lain masyarakat dihadapkan oleh zaman di mana teknologi mulai melakukan ekspansi ke semua lini kehidupan manusia. Counter discourse terhadap perkembangan teknologi tidak dapat dilakukan, tetapi mengurangi dampak negatif dari adanya teknologi masih dapat dilakukan oleh masyarakat dengan syarat mereka mampu menganalisis kebutuhan mereka terhadap teknologi. Masyarakat kritis adalah suatu kunci untuk menciptakan masyarakat sejahtera, perbedaan kebutuhan antara individu-individu adalah mutlak, bila dikembalikan kepada tujuannya, teori kritis menghendaki terbentuknya masyarakat 
yang kritis terhadap segala sesuatu menyangkut kehidupan, sehingga perubahan dapat bergulir dan terlaksana dengan cepat.

Selain problematika masyarakat postmodern disebabkan oleh masifnya perkembangan teknologi, kapitalisme sebagai bagian yang menggunakan teknologi untuk keperluan legitimasi kekuasaannya di era ini semakin menempati tampuk kekuasaan. Bukan hanya didukung oleh teknologi, sebagian besar pemerintah baik di negara-negara maju dan berkembang kurang efektif dalam menekan dominasi yang dilakukan oleh pemilik modal. Sebut saja sebagai contoh di salah satu daerah seorang petani dipenjarakan lantaran memanen kelapa sawit yang dia tanam sejak kecil bersama ibunya, lantaran kepemilikan lahan yang masih sengketa dengan salah satu perusahaan besar. Tujuan dasar dari teori kritis untuk mengubah masyarakat ke arah yang jauh lebih baik dapat di daya gunakan untuk mencapai masyarakat sejahtera, maka dari itu apabila pemikiran Jurgen Habermas yang menjelaskan keterkaitan antara ilmu dan kepentingan manusia secara teknis (technical), Praktis (practical) dan emansipatoris (emancipatory) ${ }^{25}$ di terapkan ke dalam kehidupan masyarakat industri maka tujuan humanisasi dan emansipatorisasi dapat terwujud. Namun, perlu dipahami bahwa untuk menciptakan masyarakat kritis terhadap situasi kekinian perlu pendalaman konsep mengenai apa sesungguhnya teori kritis. Teori kritis tidak dapat diajarkan secara sepihak sehingga pihak yang mengajarkan akan mendominasi pemikiran orang yang diajar, karena tentunya dominasi adalah hal yang sangat ditentang dalam pemikiran tersebut. Pada akhirnya pembelajaran masyarakat terhadap teori kritis harus dilakukan secara komprehensif sehingga masing-masing individu memiliki pemahaman sendiri mengenai teori kritis, serta tujuan mereka dalam hidup dikarenakan setiap individu mempunyai definisi tersendiri dalam mengartikan sesuatu sebagai contohnya pengertian sejahtera tentunya dimaknai dalam berbagai definisi berbeda-beda. Dengan demikian, tujuan dari teori kritis dapat tercapai yakni perubahan masyarakat ke arah yang jauh lebih baik.

\section{SIMPULAN}

Teori kritis adalah teori yang mempunyai ruang lingkup yang sangat luas. Teori ini lahir dalam rangka proses kritis yang dilakukan oleh Mazhab Frankurt terhadap

\footnotetext{
${ }^{25}$ Kamaruddin, Paradigma Kritis IImu Sosial dan Komunikasi, Aceh: Universitas Malikussaleh, 2013, hlm. 6
} 
kondisi masyarakat industri. Para ahli, menyoroti ketidakberhasilan sistem kapitalis yang didukung oleh positivisme dalam mengubah masyarakat ke arah yang lebih maju. Liberalisme sebagai sistem yang menggantikan sistem lama tidak melepaskan keterbelengguan manusia, namun membuat suatu sistem dominasi baru yang menyebabkan adanya perspektif One Dimensonal Man. Kegagalan yang terjadi menyebabkan timbulnya masyarakat yang tidak emansipatoris. Untuk mengatasi hal tersebut teori kritis menawarkan solusi yang dapat dilakukan dengan cara menciptakan masyarakat kritis yang berfikir secara komprehensif, memperhatikan historisme serta masyarakat yang mampu mempraktikkan teori yang telah ada untuk keperluan bukan hanya jasmani tetapi kebutuhan substansi manusia yang lain yakni rohani.

Menyikapi kondisi masyarakat di abad ke dua puluh satu, atau yang lebih sering disebut sebagai era disrupsi di mana kapitalisme yang menyebabkan terjadinya dominasi antar manusia semakin berkembang, dominasi teknologi yang makin pesat, serta diperdayai-nya manusia dengan kebutuhan jasmani sehingga melupakan kebutuhan rohani yang juga merupakan kebutuhan mendasar atau substansi manusia, teori kritis masih dapat menyelesaikan berbagai permasalahan tersebut. Teori kritis bila digunakan sebagai suatu konsep berpikir dalam era disrupsi guna mengatasi masalah yang kian kompleks, masih sangat relevan dipergunakan dikarenakan masalah yang dihadapi sebagai latar belakang lahirnya teori tersebut menyangkut problematika yang serupa walaupun di era disrupsi jauh lebih kompleks. Selain itu, adanya tujuan teori kritis untuk mencapai masyarakat kritis, berkeadilan dan bersifat emansipatoris dapat membawa masyarakat ke arah perubahan yang jauh lebih baik dalam menciptakan kehidupan dan komunikasi yang lebih hangat sesama manusia.

\section{DAFTAR PUSTAKA}

Ahmad Suhelmi, Pemikiran Politik Barat, Gramedia Pustaka Utama, Jakarta, 2001.

Ajat Sudrajat, (tanpa tahun). "Jurgen Habermas: Teori Kritis Dengan Paradigma Komunikasi”, taken form http://staff.uny.ac.id/dosen/prof-dr-ajat-sudrajatmag., on November, $12^{\text {nd }}, 2018$, at $5.10 \mathrm{pm}$.

A. Setyo Wibowo, Para Pembunuh Tuhan, Kansius, Yogyakarta, 2009.

Budi Hardiman, F, Pustaka Filsafat: Melampaui Positivisme dan Modernitas, Kansius, Yogyakarta, 2003. 
Bertens, Filsafat Barat Kontemporer: Inggris-Jerman, Gramedia Pustaka Utama, Jakarta, 2002.

Franz Magnis Suseno, Pijar-Pijar Filsafat: dari Gatholoco ke Filsafat Perempuan, dari Adam Müller ke Postmodernisme, Kansius, Yogyakarta, 2005.

Fx Adji Samekto, Studi Hukum Kritis: Kritik Terhadap Hujum Modern. Pustaka Pelajar, Yogyakarta, 2005.

Ginting Suka, "Dominasi dalam perspektif Teori Kritis", Jurnal Antropologi, Volume XII, No. 1, 2012.

Iwan, "Menelaah Teori Kritis Jurgen Habermas", Jurnal Edueksos: Jurnal Pendidikan Sosial dan Ekonomi, Vol III No. 2, 2014.

Kamarudin, Paradigma Kritis Ilmu Sosial dan Komunikasi, Universitas Malikussaleh, Aceh, 2013.

Munir Fuady, Filsafat dan Teori Hukum Postmodern, Citra Aditya Bakti, Bandung, 2006.

Marcuse, Herbert, One Dimensional Men: Studies in the Ideology of Advanced Industrial Society, Routledge \& Kegal Paul, London, 1964.

Paulus Rudolf Yuniarto, "Masalah Globalisasi Indonesia: Antara Kepentingan, Kebijakan dan Tantangan”, Jurnal Kajian Wilayah, Volume 5, No. 1, (2014).

Pollack, Friederich, Studies in Philosophy and Social Since, The Institute of Social Reserch, New York, 1941.

Rapar, Jan Hendrik, Pengantar Filsafat, Kansius, Yogyakarta, 2015.

Rush, Fred. The Cambridge Companion to Critical Theory: Cambridge companions to philosophy, religion, and culture. Cambridge University Press, Inggris, 2004.

Sindung Tcahyadi, “Teori Sosial Dalam Perspektif Teori Kritis Max Horkheimer", Jurnal Filsafat, Volume 17, No 1, 2007.

Wallerstein, Immanuel, "Eourocentrism and Its Avatar: The Dilemas of Social Science", SAGE Journals: Sociological Buletin, (46) 1, March (1997).

Yesril Anwar, Pengantar Sosiologi Hukum, Gramedia Widiasarana, Jakarta, 2011

Zaprulkhan, Filsafat Ilmu: Sebuah Analisis Kontemporer, Depok: Rajagrafindo, 2019.

Zuhri, "Hermeneutika dalam Pemikiran Jurgen Habermas", Jurnal Filsafat dan Pemikiran Islam; Refleksi, Volume 4, No. 12004. 